\title{
チアゾリルアゾフェノール類の核磁気共鸣と電子スペクトルとの関係*., *2
}

(昭和 42 年 4 月 21 日受理)

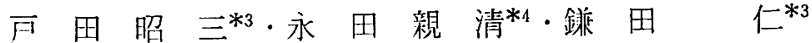

7 種類のチアゾリルアゾフェノ一ル類の四塩化炭素，クロロホルム，フセトソ溶液中における核磁気共鳴スペクトルの化学シフ トと，これらの溶液中における電子スペクトルの関係を検討した。

これらの溶液中でのキノンヒドラゾンーフェノールアゾ互変異性体のモル分率は電子スペクトルを各吸收帯に分離して推定した。 $\tau=-1.0 \sim-2.0$ の間に現われる NMR シグナルの化学シフトは，それぞれの溶媒についてフェノールフゾ異性体のモル分种に 対して直線的に変化した。したがって，この互変異性体間の交捘速度は常温でも十分速いことを示している。

紫外可視部における両異性体の吸収帯の荇重平均位置と NMR 化学シフトとは一定の関係を示した。さらにベンゼン環の3-位 プロトンの化学シフトは分離ざれた吸収带の位置とよい関連性をもつととがわかった。

\section{1 緒 言}

著者らは金属試薬として使用されているチアゾリルアゾフェノ ール誘導体の NMR スペクトルを測定して，その化学シフトや カップリング定数などリを調べた。また についても検討2をを行なった。今回はこの誘導体の電子スペクト ルから得られる情報と NMR の化学シフトとの関連性を調べて みた。その結果ベンゼン環プロトンの化学シフトとは異なり， 值が 0〜ー2.0 の間に現われる OH プロトンシグナルの挙動 は，著者らが他のアゾ化合物で赤外吸収スペクトル3) 5)などから 予想したこととは一致しなかった。そこで Shoolery ら²), Reeves $^{7),}$ 近藤ら8)が $\beta$-ジケトンについて報告しているような互変 異性体間の交換を考慮して，NMR シグナルと可視吸収スペクト ルとの関連性を検討した。

\section{2 実験}

\section{1 測定試料}

測定試料は金属材料研究所の川瀬 晃氏から提供を受けたもの で，構造式および融点は既報1に示すとおりであり，つぎの 8 種 類である。すなわち 2-(2'-チアゾリルアゾ)-4-メチルフェノール (以後 CT と略記する)；2-(2'-チアゾリルアゾ)-4,6-ジメチルフ

*1 この報交を“アソフフェノール化合物の核磁気共鳴スペク トルによる研究(第 3 報)”とする

*2 前報(第 2 報), 鎌田 仁, 戸田昭三, 永田漞清, 日化, 88, 818(1967).

*3 Shozo TODA, Hitoshi KAMADA 東京大学工学部工業分 析化学教室, 束京都交京区本郷

*4 Chikakiyo NAGATA 芝浦工業大学工業化学科, 東京都 港区芝浦

1) 鎌田 仁，戸田昭三，永田親清，日化，88，24(1967).

2) 前報(第 2 報), 鎌田仁, 戸田炤三, 永田親清, 日化, $88,818(1967)$.

3） 戸田昭三，日化，80，402(1959)。

4) 戸田昭三，小泉 操，日化，81，1292(1960).

5）戸田昭三，小島幸夫，日化，88，18(1967)

6) H. S. Jarret, M. S. Sadler, J. N. Shoolery, J. Chem. Phys., 21, 2092(1953).

7) L. W. Reeves, Can. J. Chem., 35, 1351(1957).

8) 近藤一患, 近藤㚙和, 竹本常松, 池上恒男, 工化, 68, $1404(1965)$
-ノール(DMT) ; 2-(4'-メチル-2'-チアゾリルアゾ) -4, 6-ジメチ ルフェノール(MDMT); 2-(4'-メチル-2'-チアゾリルアゾ) -4-メ トキシフェノール(MMT); 2-(4', 5', 6' , 7'-テトラヒドロベンゾ2'-チアゾリルアゾ)-4-メチルフェノール(HCT)；2-(2'-チアゾ リルアゾ)-4ーフェニルフェノール(DPT*5)の 8 種類を使用した。

\subsection{NMR スペクトルの測定}

NMR スペクトルの測定条件は既報》に示したとおりであり， 日本電子工業株式会社 G-60 型により TMS を内部標準として 測定した。

\section{3 電子スペクトルの測定}

吸収スペクトルの測定は日本分光工業株式会社 UV-175 型分 光光度計により，ネオジムガラスにより波長を補正した。試料調 裂は約 4〜 $6 \times 10^{-5} \mathrm{~mol} / l$ の四塩化炭素，アセトン，およびク口 ロホルム溶液で，10 $\mathrm{mm}$ の石英セルを用いて行なった。

\section{3 結果および考察}

\section{1 “水酸基プロトン” の化学シフトと互変異性}

これらの誘導体の四塩化炭素溶液, 重クロロホルム溶液および アセトン溶淮での NMR スペクトルは既報2に示したように， $\tau$ 值が約 0.0 から -2.5 の間に一重線が 1 本現われる(RT のみ

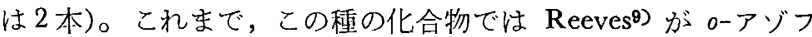
ェノール類の NMR スペクトルを測定して, 四塩化炭素溶液 ではフェノール形互変異性体として存在していることを報告して

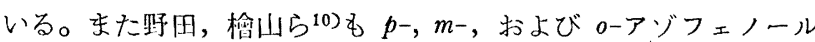
について測定を行ない，OH プロトンによる吸収が $\tau$ 价で -2 付近に現われ。一体は他の異性体と比校して置換歰の影響を大き く受けることを報告している。著者らも前報においては，この シグナルを $\mathrm{OH}$ プロトンによるものであり $\mathrm{CH}_{3}$ プロトンの強 度と比較して $1: 3$ であることから，この誘導体はフェノールア

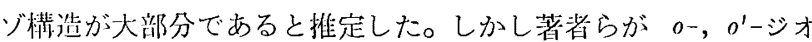<smiles></smiles>

9) L. W. Reeves, Can. J. Chem., 38, 748(1960).

10)㶦田健一郎, 黾尾贵, 平島恒亮, 真鍋修, 恰山八郎, 日本化学会第，20 年会满演予稿集 N，(1967)p. 508 . 
キシアゾ化合物において，赤外吸収スペクトルから得られたオル ト位の官能基の挙動と電子スペクトルとの関係334から予想され る $\mathrm{OH}$ プロトンの化学シフトと紫外可視吸収スペクトルとの関 係は一致しなかった。

そこでこの誘導体ではつぎのように考察してみた。すなわち网 1 に示した電子スペクトルでは二つ以上の吸収带が加られ, Burawoy ${ }^{11) 13)}, \mathrm{Kuhn}^{12)}, \mathrm{Hadzi}^{14)}$ ，新宮15)らが

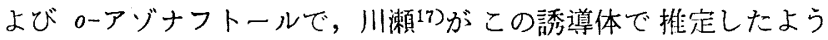
に，つぎのような互変異性について考慮しなければならない(四 塩化炭素溶媒の電子スペクトルも大体図 1 と同じ)。

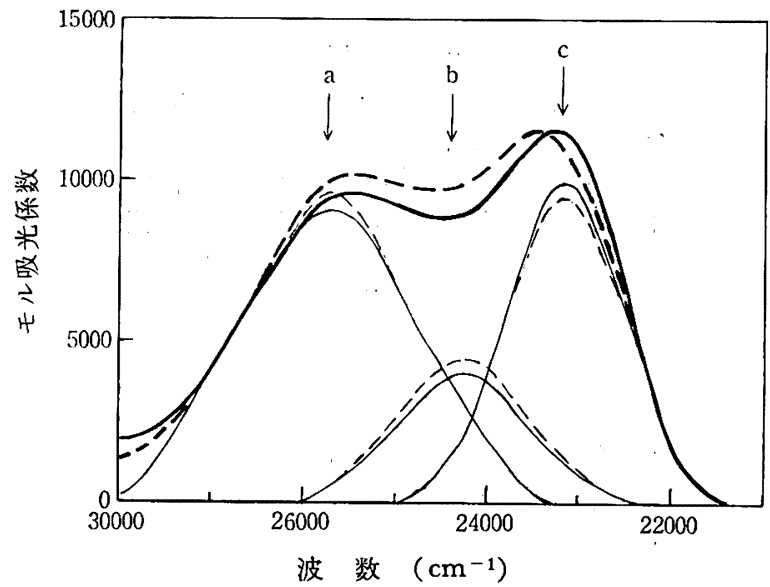

一：アセトン溶液，—：分離した吸収帯 ---：クロロホルム溶液, ----: 分離した吸収带

困1 HMT の吸収スベクルと分離した吸収帯

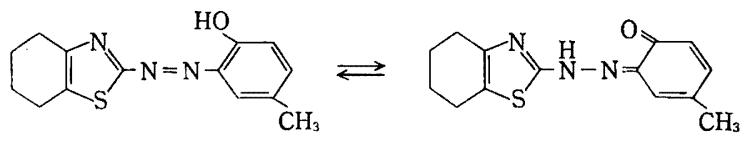

[1]

(2)

この誘導体ではアセチルアセトンの常温における互変異性など でみられるように両異性体間の交換速度が遅く, NMR スペクト ルに両異性体に基づくシグナルが分離して現われるようなもので なく，〔1]と〔2]の交換速度が速く，1 本の NMR シグナルし か現われなかったものと推定される。交換速度の速い場合の化学 シフトは，その異性体のおのおのの化学シフトの荷重平均位置に 出現する16)と考えられるので，この誘導体におけるフェノールア ゾ楧造〔 1 〕のモ分率と $\tau=-1.0 \sim-2.0$ のシグナルの化学シ フトとの関係を検討して確認してみた。

\section{1 .1 電子スペクトルよりフェノールアゾ構造の モル分率の}

11) A. Burawoy, I. Markowitsch, Ann., 503, 180(1933); 504, 71(1933); 509, 60(1934).

12) R. Kuhn, F. Bär, ibid., 516, 143(1935).

13) A. Burawoy, A. R. Thompson, J: Chem. Soc., 1953, 1443.

14) D. Hadzi, ibid., 1956, 2143.

15）新宫春推，日化，60，542(1939).

16）たとえば, J. A. Pople, W. G. Schneider, H. J. Bernstein, "High-resolution Nuclcar Magnetic Resonance", McGraw-Hill, New York(1959)10 章，17章など.

17）川瀨 光, 東京大学学位論文, “チアゾリルアゾ錯体の 工椾分析化学一の応用に関する研㚾”，(1964)p. 137.

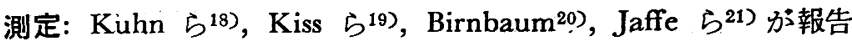
しているように，乙の領域の吸収スペクトルは対称な吸収帯の集 りからなると考え，チアゾリルアゾフェノール類の電子スペクト ルを吸収帯に分離してみた。その具体的方法は波数等間隔目盛に 変換したのち，Vandenbelt, Henrich ${ }^{22)}$ の報告を参照とし，ス ペクトルを最少数の対称形な吸収帯からなるようにくり返し作四 して分離を行なった。一つの吸収帯の形は大体 Gauss 曲線にな るようにした。その結果図1の細線で示されるような三つの吸収 帯を得た。

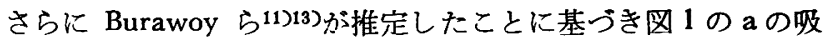
収带はフェノールアゾ構造〔1]によるものの一つであり，c吸収 帯はキノンヒドラゾン構造〔2】によるものの一つであると考え た。ここで，a吸収帯の吸収強度と $\mathrm{c}$ 吸収帯の吸収強度との間に は大きな差がないと考えられるので, 図 1 のスペクトルが得られ た溶液中ではフェノールアゾ互変異性体[1]のモル分率は近似的 に， $A_{\mathrm{a}} / A_{\mathrm{a}}+A_{\mathrm{c}}$ として求められる。ここに $A_{\mathrm{a}}, A_{\mathrm{c}}$ は $\mathrm{a}$ および $\mathrm{c}$ 吸収帯の面積強度*6である。

表 1 に四塩化炭素，クロロホルムおよびアセトン溶液における フェノールアゾ互变異性体とキノンヒドラゾン互変異性体の吸収 帯の位置, および 3 種の溶媒中におけるフェノールアゾ異性体の モル分率を推定した值を示した。

表 1 チフゾリルフソフェノール誘導体の互変異性体の 吸収位置およびアゾフェノール体のモル分率

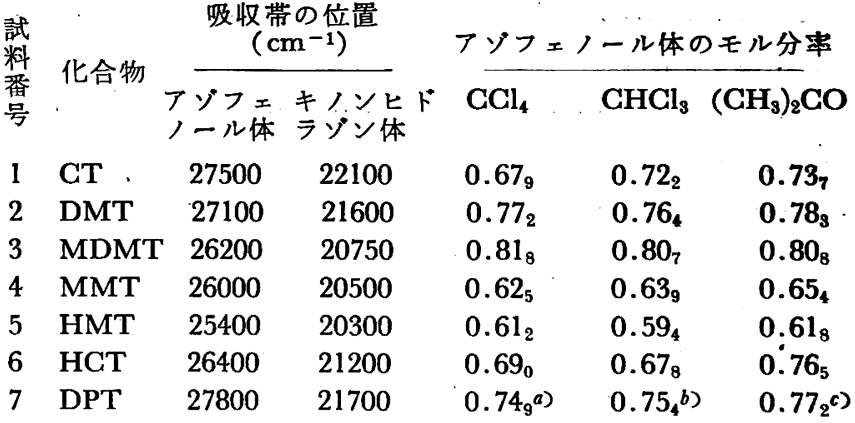

注 $a$ ）この化合物の低磁場シグナルは $\tau=-1.61 . b) \tau=$ $-1.65 . c) \tau=-1.50$.

18) W. Kuhn, E. Braun, Z. Phys. Chem., B 8, 281 (1930); B 9, 428(1930).

19) A. Kiss, M. Gerendas, ibid., A180, 117(1937).

20) P. P. Birnbaum, J. H. Linford, D. W. G. Style, Trans. Faraday Soc., 49, 735(1953).

21) H. H. Jaffe, M. Orchin, "Theory and Application of Ultraviolet Spectroscopy ", John Wiley N. Y.(1962) p. 111; H. H Jaffe et al., J. Mol. Spectry., 2, 120 (1958).

22) J. M. Vandenbelt, C. Henrich, Appl. Spectry., 7, 171 (1953).

*6 面積強度 $A$ はつぎのようにして計算した。

$$
\begin{aligned}
A= & \int \varepsilon(\nu) \mathrm{d} \nu= \\
& \varepsilon_{\max } \int \exp \left\{-\left(\frac{\nu-\nu_{\max }}{h}\right)^{2}\right\} \mathrm{d} \nu=\varepsilon_{\max } h \sqrt{\pi}
\end{aligned}
$$

$h$ は $\varepsilon=\varepsilon_{\max } / e$ における位置の吸収帯の幅 $\Delta \nu_{1 / e}$ の $1 / 2$ の值.

したがって, 近似的には $h V \bar{\pi}=\frac{1}{2} \Delta \nu_{1 / e} V \bar{\pi}$ を $\varepsilon_{\max } / 2$ における位置での吸収帯の幅 $\left(\Delta \nu_{1 / 2}\right.$ ：半值幅)と等しいと して $A=\varepsilon_{\max } \cdot \Delta \nu_{1 / 2}$ によって計算した。 


\section{1 .2 呧磁場シグナルの $(\tau=-1.0 \sim 2.0)$ の化学シフトとつ} ェノールアゾ異性体のモル分率との関係: 三つの溶媒中に和ける “水酸基プロトン” の化学シフト2)とフェノールアゾ異性体のモ ル分率との関係は図 2 のように直線関係を示している。したがっ て十分速い速度で $\mathrm{OH}$ と $\mathrm{NH}$ の間でプロトン交換がおきてい ると考えられる*。

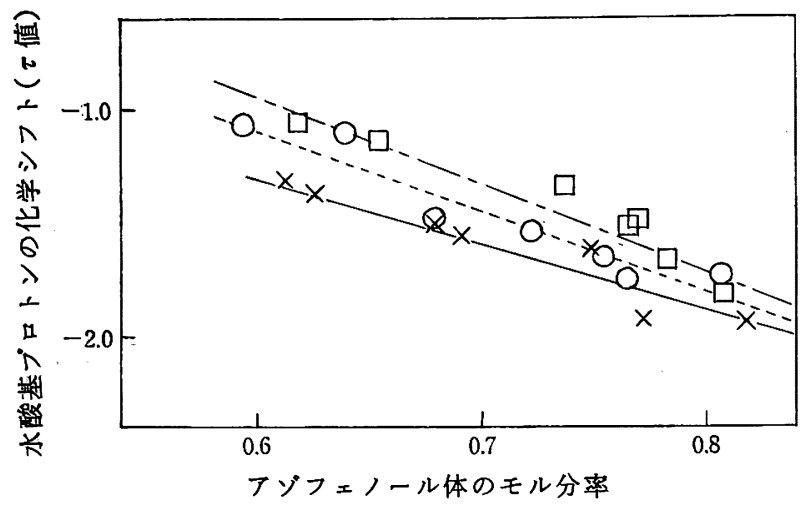

-ーロ-—：アセトン溶液, --○--：クロロホルム溶液 -X一: 四塩化炭素溶液

図 2 水酸基プロトンのて值とアゾフェノール体 の濃度との関係

ここで問題となるととは電子スペクトルと NMR スペクトル を測定するときの濃度が異なることである。しかし，この誘導体 では分子内水素結合が強いため，濃度による影響はあまり大きく ないと考光られる。

図 2 における各直線間の差はオルト位の官能基に対する溶媒の

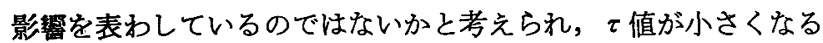
ほど溶媒間の差が少くなることは，異性体のモル分率が変化する ことのほかに，分子内水素結合の度合が強くなり，溶媒の影響を 受けにくくなった結果と考光られる。

常温で測定した場合， $\tau=-1.0 \sim-2.0$ の化学シフトのシグ ナルはプロトン交換の速度が速いので， OH プロトンと NH プ ロトンの化学シフトの荷重平均位置として現わされているので直 接紫外可視部の吸収最大位置と関連づけることはできなかった。

そてで，表 1 亿示してある吸收位置と面積強度から，フェノー ルアゾ構造〔1】の示す吸収最大位置とキノンヒドラゾン構造〔 2】 の示す吸収最大位置の荷重平均位置とを計算し，NMR スペクト ルの示す化学シフトとの関係を調べてみた。その結果図 3 に示す ように, 大体紫外可視部の吸収位置と NMR の化学シフトとは関 係のあることがわかった。この図 3 で各点がばらつき，その関連 性が必ずしも明嘹でないのは，抢そらくスペクトルを分離したと きの誤差が $\nu_{\max }, \varepsilon_{\max }$ および $\Delta \nu_{1 / 2}$ の中にむ入ってきて，そ れらにより計算される荷重平均位置に大きく響いてきたためであ ろう。最近市販されている電子計算器を用いた波形解析装置を使 用し，吸収帯の分離を正確に行なえば，もっとよい関連性が得ら れるものと思われる。

\section{2 ベンゼン環プロトンの化学シフトと電子スペクトルとの} 関保

*7 著者らは既報において，NMR スペクトルのみから，乙 れら溶媒中ではフェノールフソ異性体が大部分の割合を 占めるとした推定は誤りであったてとを示している。

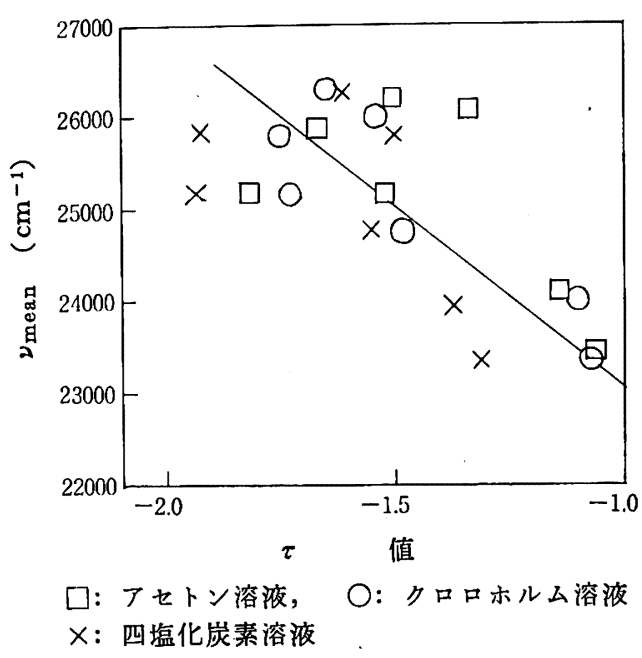

因 3 “ $\mathrm{OH}$ プロトン” シグナルの化学シフトと電子スペ クトルにおける荷重平均吸収最大位置との関俰

図 1 で分離した吸収帯 a と c の位置とベンゼン環の 3 の位置に おける化学シフトとの関係を示すと図4のようになる。

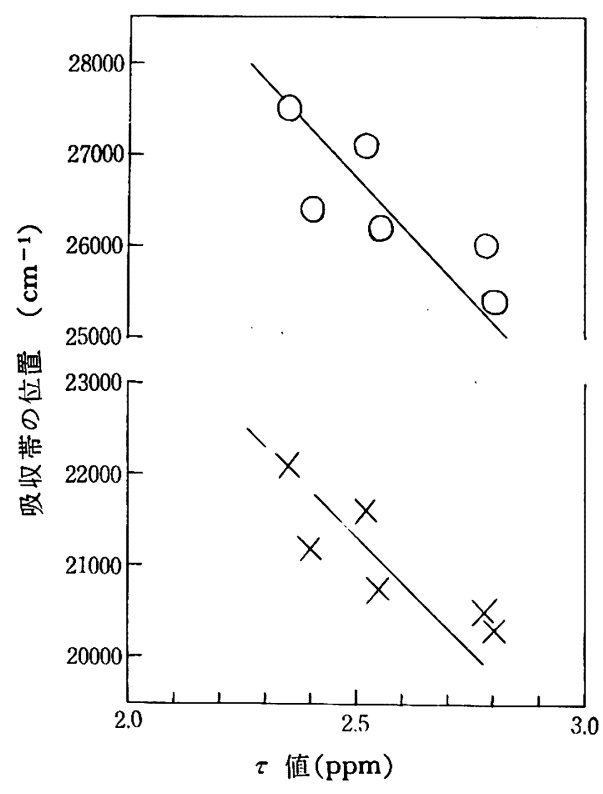

ヘンンゼン環 3 位プロトソの化学シフト值

○: アゾフェノール体， $\times$ : キノンヒドラゾン体

図 4 ベンゼン環 3 位プロトンの化学シフトと 紫外可視吸収位置との関俰

3 の位置のプロトンは，アゾ基に近いため，その影響を直接受 けていると考えられ，したがって化学シフトは紫外可視部におけ る吸収带と図 4 のような関係を示したと考えられる。すなわち，<smiles>Oc1ccccc1N=Nc1nccs1</smiles>

3 位プロトンの化学シフトは $\mathrm{OH}$ 基と $-\mathrm{N}=\mathrm{N}-$ 基のキレート環, $\mathrm{H}$

あるいはその互変異性体である $\mathrm{C}=\mathrm{O}$ 基と $-\mathrm{N}-\mathrm{N}=$ 基とのキレー 卜環の状態を示すものと考えることができる。

終りに試料を提供された金属材料研究所の川瀬 晃博士に厚く 感謝致します。 